\title{
Closing Gender Asset Gap in Land Access and Control in A1 Schemes in Zimbabwe
}

\author{
Tavonga Njaya $(\mathrm{PhD})$ \\ Faculty of Commerce and Law, Zimbabwe Open University, Zimbabwe
}

\begin{abstract}
The study reflected on the impact of the fast track land reform programme, 2000-2002 on the distribution of land between men and women in Al resettlement areas in Zimbabwe. Throughout the discourse on the land reform programme, the virtues of land transfer have been extensively extolled while ignoring its impact on gender relations and gender asset gap.

The study used a national quantitative baseline survey and qualitative data collected in Goromonzi District. Qualitative data were collected through in-depth interviews, direct observations and documentary analysis so as to triangulate the evidence. This dataset was used to complement findings from statistical analysis of the survey data.

The chi-square tests on survey data and findings from the case study conducted in Goromonzi District did not show evidence of discrimination against women under the fast track land reform programme. Instead, women tended to obtain more rights to land through two avenues: obtaining land as individuals in their own right and through the joint registration of offer letters with their husbands. The results showed that women beneficiaries obtained the same land rights as men in terms of land use patterns.

The study recommended that allocation of land under the land reform programme should focus on individuals within households. Government officials directly involved in the design, planning and implementation of the land reform programme should be trained in gender analysis and participatory gender planning. Methods should be devised to inform women about their land rights and the avenues through which these rights can be enforced.
\end{abstract}

Keywords: Al model; asset; chi-square; household; gender asset gap; statistical analysis; women

\section{Introduction}

Land is an important resource especially for an agricultural economy. It constitutes the primary form of wealth and source of economic and political power (Deere and Doss, 2006). In Zimbabwe, where the majority of people obtain their livelihood directly from agriculture, land ownership and use have always been highly emotional, sensitive and contested issues.

At independence in 1980, Zimbabwe had a dual agricultural sector (Deininger, Hoogeveen and Kinsey, 2002) and a racially skewed land distribution system (UNDP, 2002; Weiner, 1988 cited in Chaumba, Scoones and Wolmer, 2003). The commercial agricultural sector was dominated by whites and foreign owned companies while the indigenous blacks constituted the small-scale agricultural subsector. All land in the communal areas belongs to the state and usufruct rights are given to the head of the household, usually male, by the local chief.

The primary goal of the land reform programme was to address the imbalances in land access while alleviating population pressure in the communal areas, extend and improve the base for productive agriculture in the smallholder farming sector and bring idle or underutilised land into full production (Kinsey, 1999). Besides redistributing land, the first phase of the land reform programme also focused on developing rural areas through the provision of infrastructure and other socio-economic services so as to ameliorate the plight of the people negatively affected during the war of liberation (Zuwarimwe, 1999 cited in Masiiwa and Chipungu, 2004).Zimbabwe experienced two phases of the land reform. The First Phase of the Land Reform and Resettlement Programme (Phase I) was launched in September 1980. The aim of the government was to resettle 162,000 families and acquire 8.3 million hectares of land from white commercial farmers for the purpose (GOZ, 1998b). Two methods of land acquisition were used during Phase I, namely, land acquisition through the market (willing seller-willing buyer) and compulsory land acquisition. The Second Phase of Land Reform and Resettlement Programme (Phase II) was characterised by spontaneous land occupations (seizures). The scale and intensity of farm invasions and occupations increased after the rejection of the draft constitution in February 2000 (Sachikonye, 2003, Marongwe, 2008). The farm invasions and occupations were spearheaded by District War Veterans Associations who mobilised people from neighbouring communal areas (Chaumba et al., 2003; Scoones et al., 2010). The reasons why the government condoned farm invasions after the referendum included declining popularity of the ZANU-PF government; the question of allocation of multiple farms to the elite; lack 
of financial reserves to implement the land reform programme; rising pressure for land from landless people (Moyo 1998 cited in Sithole et al., 2003) and rising popularity of the Movement for Democratic Change in the face of impending elections in June 2000 (Chaumba et al., 2003; Madhuku, 2004; Masiiwa and Chipungu, 2004). It is important to note that the land occupations were not unique to Zimbabwe. Similar programmes have been implemented in countries such as Brazil where land reforms are a response to land occupations (Marongwe, 2002a).

The Fast Track Land Reform Programme was officially launched on 15 July 2000 in order to formalise and regularise the haphazard farm occupations and encourage further land appropriation and redistribution (Goebel, 2005). The government enacted the Rural Land Occupiers (Protection from Eviction) Act (2001) in order to legalise all land occupations which took place from 16 February 2000 to March 2001 (Madhuku, 2004; Masiiwa and Chipungu, 2004). The Fast Track Land Reform Programme (FTLRP) involved surveying and pegging the already invaded farms (Chaumba et al., 2003). It was designed to be undertaken in an accelerated manner and was a fundamental departure from previous philosophy, practices and procedures of acquiring land and resettling people (GOZ, 2003).

There are two models for resettlement under the FTLRP, namely model A1 and model A2. Model A1 aimed at decongesting communal areas and was meant for the generality of the landless people (GOZ, 2003). There are two variants of this model: A1 villagised model and A1 self-contained variant. For the village model, an individual family farm is six hectares plus a common grazing land (GOZ, 2001). In A1 self-contained units, farmers settle in self-contained plots (or farms) that can be used for crops and livestock. Model A2 was based on full cost recovery from the beneficiary and was aimed at creating a cadre of 51,000 small-medium and large scale black indigenous commercial farmers $(\mathrm{GOZ}, 2003)$ and de-racialise the commercial agricultural subsector (UNDP, 2002). The resettlement areas changed the distribution of land and the construction of land tenure regimes. Although both A1 and A2 schemes are untitled, farmers have offer letters as evidence and a guarantee of security for their access to land (UNDP, 2002). Through these land tenure regimes the unequal access to and control over land remained the major problem confronting married women in the resettlement areas. How many married women obtained land in their own right under the FTLRP? How secure are married women's land rights in resettlement areas? These were the overarching questions addressed in the study. The number of femaleheaded households who benefited under the A1 model was a mere 18 percent (GOZ, 2003). This should be an area of concern as was the case when minority white commercial famers owned 45 percent of the agricultural land in 1980.

\section{STUDY OBJECTIVES}

The primary aim of the study was to make a systematic and critical evaluation of the distribution of land between men and women in A1 resettlement areas to establish if there was any gender asset gap in land access. The specific objectives of the study included the following:

- To characterise land access and control in terms of sex, marital status and landholding in A1 resettlement areas to establish if there was any discrimination against women.

- To assess if women have the same land rights as men in A1 resettlement areas in terms of mean farm size, soil type (or quality) and availability of farm infrastructure.

- To make recommendations for policy intervention that will strengthen equal access to and control over land between men and women.

\section{RESEARCH QUESTIONS}

The following were the research questions for the study:

- How can land access and control be characterised to determine the effects of the fast track land reform programme on women's land rights?

- Do women have the same land rights as men in A1 resettlement areas in terms of mean farm size, soil type (or quality) and availability of farm infrastructure?

- What policy recommendations can be made from the study?

\section{HYPOTHESES OF THE STUDY}

The above research questions were operationalised using the following three hypotheses (H1-H3) derived from the model and relevant literature.

H1: Women's access to and control over land were neglected during the implementation of the fast track land reform programme.

This hypothesis was tested using statistics on the distribution of land between men and women. This was possible because A1 farmers have offer letters that confirmed their access to and control over land. The test was done by comparing landholding in the following categories: household head; spouse; joint-registration and other(s). The hypothesis would be rejected if there is a statistical difference between the relative distributions of 
offer letters in the four categories. Another dimension tested in the study was whether or not women had the same rights to land as men and in the process measured the gender-asset gap in A1 resettlement areas. This was done by examining land use patterns with regards to the size and type and/or quality of the land owned and cultivated by women and men. This necessitated two more hypotheses.

H2: Women tend to have smaller arable plots than men.

H3: $\quad$ Women tend to have land rights to farm holdings with worse soil type (or quality) than men.

Hypothesis 2 was based on the assumption that Zimbabwe is a patriarchal society and men were likely to get larger

arable plots than women. The hypothesis sought to determine the magnitude of the gender-asset gap in access to and control over land. The differences in the sizes of fields was tested with t-test for mean sizes for arable land cultivated by men and women. Hypothesis 3 was derived from hypothesis 2 . If women were given smaller arable plots than men, then the researcher expected those plots to be of marginal quality. Hypothesis 3 was tested using chi-square test which tested the independence or otherwise of the land type and/or quality and sex of the farm holder.

\section{Study Methodology And Design}

The study used a national quantitative baseline survey and qualitative data collected in Goromonzi District. The study used a mixed methods design where the case data occupied a secondary role to the variableoriented national survey data. These two approaches were integrated throughout the analytic and interpretive phases of the study. The household survey data was collected by the African Institute of Agrarian Studies between November 2005 and December 2006. The survey covered six districts in different provinces of Midlands, Masvingo, Matabeleland South, Mashonaland East, Mashonaland West and Manicaland. The baseline survey data contained considerable breadth and covered key variables required to test the hypotheses of the study using statistical analysis.

The collection of qualitative data was meant to give a better understanding of gender relations on access to and control over land in A1 resettlement areas. Given that the researcher was actually involved in the fieldwork and talked to A1 farmers (both men and women), Goromonzi District Administrator, District Lands Officer, the headwoman of Bains Hope, headman of Ingwenya Farms and a farm worker from Bains Hope, this generated stories about gender relations on land in A1 resettlement areas. Such stories served as good supplements to survey data analysis and more specifically assisted in exemplifying the statistical results. Five techniques were used to collect case data: questionnaire, interviews (structured and semi-structured), focus groups, observation and document analysis in order to triangulate the evidence (Bryman, 2001; Saunders et al., 2009) and hence improve the accuracy of the research findings. Of these methods, no single source had complete advantage over others. Instead, the methods were complementary to each other and where possible, they were used in tandem in order to give an in-depth understanding of gender relations on access to and control over land in A1 schemes.

The collection of case data lasted for four months, from December 2012 to March 2013. A multi-stage stratified random sampling technique was used due to the expansive nature of the study area. First, Mashonaland East Province was conveniently selected due to its relative proximity to the researcher. In the second stage, Goromonzi District was selected for budgetary and logistical reasons. Goromonzi was the only district without resettlement schemes prior to 2000 (GOZ, 2003). In the third stage, two study sites: Bains Hope and Ingwenya Farms were selected. These two farms were randomly selected from a list of former large scale commercial farms that were partitioned into A1 farms during the FTLRP. Figure 1.1 shows the two study sites of Bains Hope and Ingwenya Farms. In the fourth stage, households were stratified according to marital status: 19 women, 11 men (married to the women in the sample) and seven widows and widowers. This was because A1 farmers are not a homogenous group and a more representative sample reflecting the gender dimensions on access to and control over land could only be obtained through the stratified sampling technique. A1 farmers consist of distinct sub-populations that hold divergent views on gender relations on land and simple random sampling could not adequately reflect the balance of the different constituencies within the population. Simple random sampling was then used to select households for the sample from each stratum. 


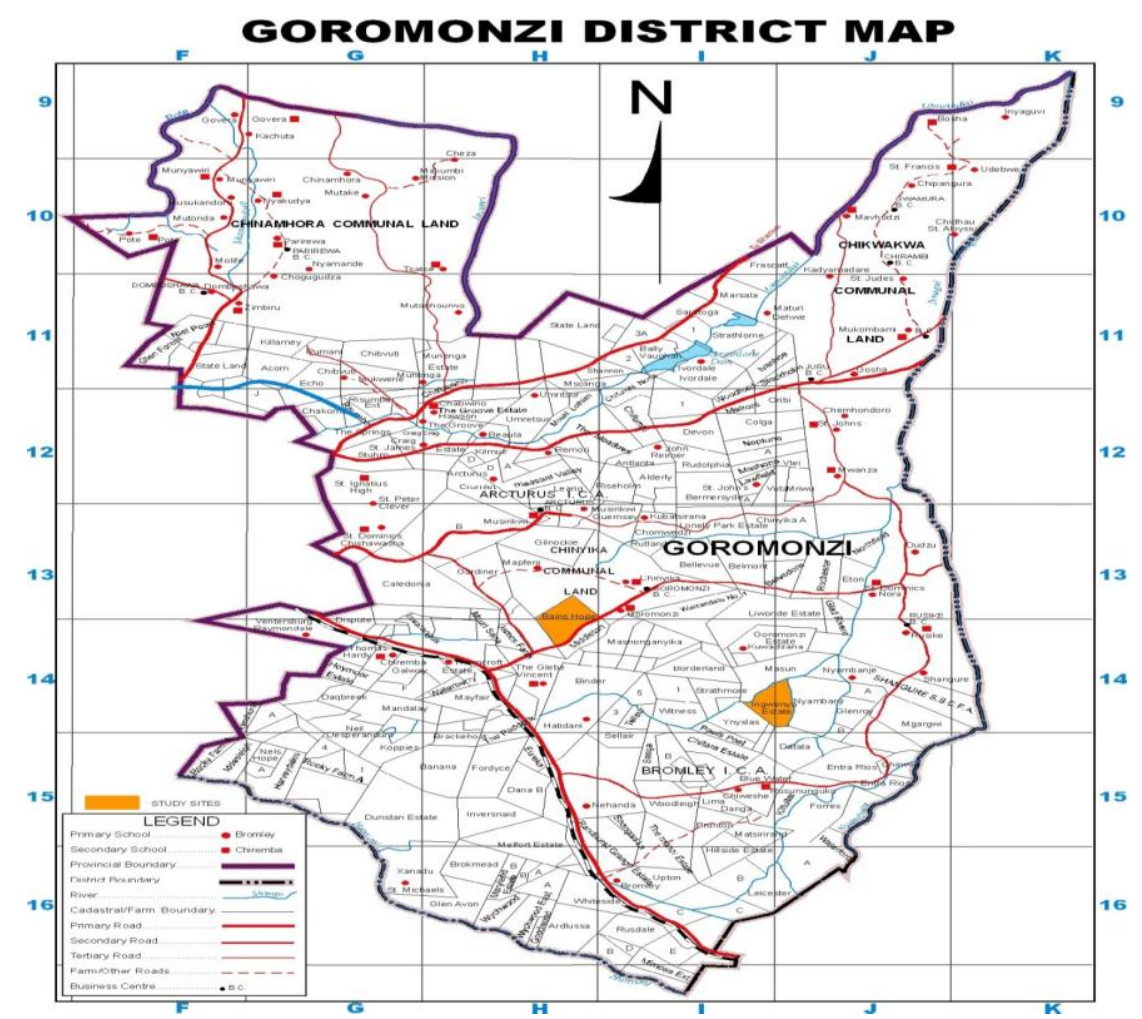

Figure 1.1: Map of Goromonzi District showing the two study sites

Source: Surveyor General, 2013

\section{Presentation Of Research Findings}

Statistical Analysis: Discrimination against women in land distribution?

The first research question asks for the effects of the FTLRP on women's land rights. The research question was used to test if women were discriminated against in the distribution of land in A1 resettlement areas. Hypothesis one (H1) was used to answer the first research question. The first hypothesis was operationalised using a chisquared test for independence or otherwise between sex and land holding.

A chi-squared test for independence was used to determine if there was any association between two attributes, availability of offer letter (Offerle) and category of landholding (farmdoc). The rationale for using the chi-square test for independence was that the variables under study, Offerle and farmdoc are categorical (Landau and Everitt, 2004); simple random sampling was used to obtain the survey data (AIAS, 2009) and the number of observations expected in each cell of the contingency table for the sampled data is more than five (Landau and Everitt, 2004).

The variable farmdoc is from the baseline survey and asks in whose name the offer letter was issued. It takes values: $1=$ offer letter issued in the name of the household head (usually male); $2=$ offer letter is in the name of the spouse; $3=$ joint registration of both spouses' names on the offer letter and $4=0$ other(s) where the offer letter is in the name of a child or relative. The "other" category also includes category where the sex of the A1 farm holder is not known. The variable Offerle is a dummy variable and specifies whether the A1 farmer has an offer letter: Offerle $=1, \mathrm{~A} 1$ farmer has an offer letter and Offerle $=0$, A1 farmer has no offer letter. A1 farmers without offer letters include squatters and those who forcibly occupied and self-appropriated the farm holdings. The test included households with couples (dualhead $=1$ ) and male-headed households $(S e x H H H=0)$ since the researcher expected married women to be deprived of their land rights under the FTLRP. On the other hand, women in single-headed households were expected to have access to land in their own right.

Under the chi-square test, what does the null hypothesis say? The null hypothesis to be tested is that there is no association between category of landholding and availability of offer letter. The categorical variable Offerle has two rows, $r$ and categorical variable (farmdoc) has four columns, $c$. The null hypothesis states that knowing the level of variable availability of offer letter does not help us to predict the level of variable category of landholding. In other words, the variables are independent. The alternative hypothesis states that knowing the level of variable availability of offer letter can help us to predict the level of category of landholding. The null hypothesis would be rejected if the p-value (to be explained below) is less than the level of significance. Support for the alternative hypothesis would suggest that the two variables are related, but the relationship is not necessarily causal in the sense that one variable "causes" the other (Gujarati, 1988, 1999; Verbeek, 2008). 
The survey data were used to conduct a chi-square test for independence which tests the null hypothesis of no association between the variables Offerle and farmdoc. In other words, the null hypothesis states that one variable does not vary according to the other. The results of the chi-squared test for independence between category of land holding and availability of offer letter are shown in Table 1.1.

Table 1.1 Chi-square test of the relationship between category of landholding and availability of offer letter

\begin{tabular}{|c|c|c|c|c|c|}
\hline \multirow[t]{2}{*}{$\begin{array}{l}\text { Do you have } \\
\text { an offer letter? }\end{array}$} & \multicolumn{5}{|c|}{ Under whose name is the farm holding registered? } \\
\hline & Household head & Spouse & Joint registration & Other & Total \\
\hline $\begin{array}{l}\text { Yes } \\
(=1)\end{array}$ & $\begin{array}{l}1233 \\
90.9 \\
81.1\end{array}$ & $\begin{array}{r}116 \\
8.5 \\
93.5\end{array}$ & $\begin{array}{c}5 \\
0.2 \\
62.5\end{array}$ & $\begin{array}{c}3 \\
0.4 \\
100\end{array}$ & $\begin{array}{c}1357 \\
100 \\
81.9\end{array}$ \\
\hline $\begin{array}{l}\text { No } \\
(=0)\end{array}$ & $\begin{array}{l}288 \\
96.3 \\
18.9\end{array}$ & $\begin{array}{l}8 \\
2.7 \\
6.5\end{array}$ & $\begin{array}{c}3 \\
0.0 \\
37.5\end{array}$ & $\begin{array}{l}0 \\
1.0 \\
0\end{array}$ & $\begin{array}{l}299 \\
100 \\
18.1\end{array}$ \\
\hline Total & $\begin{array}{c}1521 \\
91.8 \\
100\end{array}$ & $\begin{array}{c}124 \\
7.5 \\
100\end{array}$ & $\begin{array}{c}8 \\
0.5 \\
100\end{array}$ & $\begin{array}{c}3 \\
0.2 \\
100\end{array}$ & $\begin{array}{c}1656 \\
100 \\
100\end{array}$ \\
\hline \multicolumn{6}{|c|}{ Pearson Chi-square $=14.785$} \\
\hline
\end{tabular}

The results of the chi-square test show the degrees of freedom, expected count or frequencies, the test statistic, $\chi^{2}$ and the p-value associated with the test statistic. The degrees of freedom are the number of values that are free to vary after restriction has been placed on the data (Gujarati, 1999). For the chi-square test, the degrees of freedom $(d f)$ is given by:

$$
d f=(r-1)(c-1)
$$

Equation 1.1

where $r$ is the number of rows for variable Offerle and $c$ is the number of columns for variable farmdoc. The test-statistic is a chi-square random variable, $\chi^{2}$ defined by the following formula:

$$
\chi^{2}=\sum \sum \frac{\left[O_{r c}-E_{r c}\right]^{2}}{E_{r c}}
$$

where $O_{r c}$ is the observed frequency count at level $r$ of variable Offerle and level $c$ of variable farmdoc and $E_{r c}$ is the expected frequency count at level $r$ of variable Offerle and level $c$ of variable farmdoc. The summation sign, $\sum$ is written twice in equation 1.2 to indicate that we sum over the whole contingency table ( $r$ rows and $c$ columns). The p-value is the probability that the deviation of the observed from the expected is due to chance alone (no other factor acting) (Landau and Everitt, 2004).

The results of chi-square tests in Table 1.2 show a statistically significant association between variables, Offerle and farmdoc. The chi-square test statistic is 14.785 with 3 degrees of freedom and p-value of 0.002 . Since the pvalue is less than the level of significance $(\mathrm{p}<0.05)$, the researcher rejected the null hypothesis and concluded that some factor(s) was/were involved for the deviation to be so great. Rejecting the null hypothesis means that there is evidence that the relative distribution of land rights is statistically the same between the landholding constellations: offer letter in the name of the household head (who is usually male); offer letter in the name of the spouse; offer letter in the names of both spouses (joint registration) and other(s) category where the offer letter is in the name of a child or any other relative across the variable Offerle. The variable Offerle specifies if the household in the four landholding constellations has been issued with an offer letter. The test does not say anything about causality between variables farmdoc and Offerle. However, given that there is dependence between the two variables, it can be inferred that the issuance of offer letters to land beneficiaries only served to perpetuate the status quo. According to the survey data, the majority of household heads are male while women constitute seven percent.

But how do we account for the regional differences in the allocation of land between men and women in A1 resettlement areas. It is important to consider regional variations in order to capture the different sociocultural and ethnic factors in the different provinces. A chi-square test to take into account the regional differences was performed. Upon stratification by province, insignificant associations were revealed between 
variables, farmdoc and Offerle for the five provinces of Masvingo, Matabeleland South, Mashonaland East, Mashonaland West and Midlands as the p-values exceeded 0.05. The chi-square test for Manicaland Province could not be performed because all farms in the survey sample are registered under the household head whereas the tests required dualhead=1. The computed contingency tables varied across provinces because of the unavailability of data in some cells. For example, a $2 \times 2$ contingency table was computed for Matabeleland South Province while a $3 \times 3$ contingency table was computed for Mashonaland West Province. The results of the chi-squared tests are shown in the appendix, in Tables A1-5.

From the above tests, the first hypothesis is rejected because there is no evidence to suggest that women were discriminated against under the FTLRP. To the contrary, it seems women's land rights actually increased both as individuals and through joint registration of offer letters. This issue will be explained further under discussion of research findings.

\section{Land use patterns in $A 1$ schemes}

The second research question asked if women had the same land rights as men in A1 resettlement areas. The research question tried to examine the nature of land use patterns in terms of farm size and soil type and/or quality and the distribution of agricultural infrastructure between men and women. A t-test and chisquared test for independence were used to operationalise the third research question. The research question was answered through two hypotheses that tested whether women cultivated smaller arable plots than men and whether women's plots had worse soils than men's.

\section{Measuring gender-asset gap in access to and control over land in A1 schemes}

Hypothesis 2 sought to determine the magnitude of the gender-asset gap in access to and control over land in A1 resettlement areas using the mean size of arable area cultivated by men and women. The null hypothesis that the mean sizes of arable area cultivated by men and women are equal was tested using the t-test. The independent t-test was used to compare the mean arable area for women to the mean arable area for men. The group statistics for the two sub-samples are shown in Table 1.2.

Table 1.2 Group statistics for mean size arable land

\begin{tabular}{|ll|r|r|r|r|}
\hline & Sex of farm holder & \multicolumn{1}{c|}{ N } & Mean & \multicolumn{1}{c|}{$\begin{array}{c}\text { Std. } \\
\text { Deviation }\end{array}$} & \multicolumn{1}{c|}{ Mean } \\
\hline Size of arable area in ha & Male & 1238 & 8.100 & 8.4092 & .2390 \\
& Female & 308 & 8.390 & 18.3432 & 1.0452 \\
\hline
\end{tabular}

Source: Author computations from baseline survey by AIAS (2006)

The mean arable area for men is 8.1 hectares while the mean arable area for women is 8.39 hectares. This shows that female beneficiaries of land in A1 schemes have slightly larger arable area than male beneficiaries. But, is the mean difference significant? This question was answered by conducting a t-test.

Table 1.3 shows the results of the independent $t$-test between the mean arable area for men and women. The results show that the difference in the mean sizes between men's and women's arable plots is not significantly different with a p-value of 0.682 . Since the p-value is greater than the level of significance (p>0.05), the null hypothesis of equal mean arable area for men and women could not be rejected. By not rejecting the null hypothesis, the results showed that no gender asset gap existed in terms of the average arable area cultivated by men and women.

Table 1.3 Independent t-test on mean sizes of arable land in hectares

\begin{tabular}{|c|c|c|c|c|c|c|c|c|c|}
\hline \multirow{4}{*}{$\begin{array}{l}\text { Equal Var. ass. } \\
\text { Equal Var. not } \\
\text { ass. }\end{array}$} & \multicolumn{2}{|c|}{$\begin{array}{l}\text { Levene's Test for } \\
\text { Equality } \\
\text { Variances }\end{array}$} & \multicolumn{7}{|c|}{ t-test for Equality of Means } \\
\hline & \multirow[t]{2}{*}{$\mathrm{F}$} & \multirow[t]{2}{*}{ Sig. } & \multirow[t]{2}{*}{$\mathrm{t}$} & \multirow[t]{2}{*}{ df } & \multirow{2}{*}{$\begin{array}{r}\text { Sig. } \\
\text { (2-tailed) }\end{array}$} & \multirow{2}{*}{$\begin{array}{l}\text { Mean } \\
\text { Difference }\end{array}$} & \multirow{2}{*}{$\begin{array}{l}\text { Std error } \\
\text { Difference }\end{array}$} & & \\
\hline & & & & & & & & Lower & Upper \\
\hline & 1.173 & 0.279 & $\begin{array}{l}-0.410 \\
-0.271\end{array}$ & $\begin{array}{l}1544 \\
339.713\end{array}$ & $\begin{array}{l}0.682 \\
0.787\end{array}$ & $\begin{array}{l}-0.2901 \\
-0.2901\end{array}$ & $\begin{array}{l}0.7078 \\
1.0722\end{array}$ & $\begin{array}{l}-1.6785 \\
-2.3991\end{array}$ & $\begin{array}{l}1.0982 \\
1.8188\end{array}$ \\
\hline
\end{tabular}

\section{Testing gender differentials with respect to soil type and/or quality}

Chi-square test for independence was used to test the null hypothesis that there is no association between soil type (or quality) and the allocation of A1 farms to men and women. Soil characteristics were described by the predominant type of soil on the farm holding. The Soilqual variable has five categories: $1=$ red soil; 2=clay; 3=clay-loam; 4=sandy-loam; $5=$ sandy soils. The assumption here is that red soil is excellent quality; clay is very good quality; clay-loam is good quality; sandy-loam is average quality and sandy soil is 
poor quality. Table 1.4 shows the results of the chi-square test on gender differentials with respect to the predominant type of soil on the farm holding.

Table 1.4 Chi-square test on gender differentials with respect to the predominant type of soil on the farm holding.

\begin{tabular}{|c|c|c|c|c|c|c|}
\hline $\begin{array}{l}\text { Sex of farm } \\
\text { holder }\end{array}$ & & \multicolumn{5}{|c|}{ Predominant soil type on the farm holding } \\
\hline $\begin{array}{l}\text { Male } \\
(=0)\end{array}$ & $\begin{array}{l}73 \\
5.9 \\
81.1\end{array}$ & $\begin{array}{l}511 \\
41.0 \\
79.1\end{array}$ & $\begin{array}{l}537 \\
43.1 \\
79.8\end{array}$ & $\begin{array}{l}120 \\
9.6 \\
83.3\end{array}$ & $\begin{array}{l}4 \\
0.3 \\
66.7\end{array}$ & $\begin{array}{l}1245 \\
100 \\
79.9\end{array}$ \\
\hline $\begin{array}{l}\text { Female } \\
(=1)\end{array}$ & $\begin{array}{l}17 \\
5.4 \\
18.9 \\
\end{array}$ & $\begin{array}{l}135 \\
43.0 \\
20.9 \\
\end{array}$ & $\begin{array}{l}136 \\
43.3 \\
20.2 \\
\end{array}$ & $\begin{array}{l}24 \\
7.6 \\
16.7 \\
\end{array}$ & $\begin{array}{l}2 \\
0.6 \\
33.3 \\
\end{array}$ & $\begin{array}{l}314 \\
100 \\
20.1 \\
\end{array}$ \\
\hline Total & $\begin{array}{l}90 \\
5.8 \\
100\end{array}$ & $\begin{array}{l}646 \\
41.4 \\
100\end{array}$ & $\begin{array}{c}673 \\
43.2 \\
100\end{array}$ & $\begin{array}{c}144 \\
9.2 \\
100\end{array}$ & $\begin{array}{l}6 \\
0.4 \\
100\end{array}$ & $\begin{array}{c}1656 \\
100 \\
100\end{array}$ \\
\hline & \multicolumn{6}{|c|}{ Pearson Chi-square $=2.050$} \\
\hline
\end{tabular}

The chi-square test statistic is 2.050 with 4 degrees of freedom and p-value of 0.727 . Since the p-value is greater than the level of significance ( $p>0.05)$, this means that the null hypothesis cannot be rejected. The results show that there is no significant association between soil type and allocation of plots to men and women. A clear pattern showing that women's plots are of poor quality could not be discerned from the results and thus hypothesis 5 could not be sustained.

\section{Discussion Of Research Findings}

In this section, research questions are answered by integrating results from statistical tests and findings from the case study.

\section{Answering research question one}

The first research question was aimed at establishing if women were discriminated against during the FTLRP. To the contrary, the statistical tests on survey data and findings from the case study conducted in Goromonzi District did not show evidence of discrimination against women under the FTLRP. In the case study, 83.8 percent confirmed that there was equal access to and control over land in A1 resettlement areas between men and women and that there was no discrimination in the allocation of land.

An inspection of the survey data showed that there was an overall trend where women tended to obtain more rights to land through two avenues: obtaining land as individuals in their own right and through the joint registration of offer letters with their husbands. This result was what the researcher also found in Goromonzi District. For example, in Bains Hope there were more female land beneficiaries than males. Out of the 57 A1 farmers in Bains Hope, 33 were women. Out of these, 20 were married women who were allocated land in their own right. The fact that spouses jointly possessed land in resettlement areas meant that married women's position in terms of land access had improved compared to their counterparts in communal areas where access is through their husbands or male relatives. The number of jointly registered offer letters was very low for both the baseline survey and data from Goromonzi District. In Goromonzi District, jointly registered offer letters constituted a mere 8.1 percent. This was partly explained by the fact that the policy on joint registration of offer letters was implemented when the land beneficiaries had already been issued with offer letters. Another possible factor is the strength of patriarchy in the Zimbabwean society. In Goromonzi District it was found that where the wife was allocated land she would jointly register the farm holding with the husband but this was not the case with most men who registered the plots in their own names. The other factor could be attributed to the structure of the offer letter itself. The offer letter has a section for Plot Holder only and not Plot Holder(s) which hopefully could have encouraged married partners to put both names on the farm document.

The above finding is consistent with Jacobs (2000) who noted that an increasing number of married women were allocated land in their own right under Model A during Phase I of the Land Reform Programme. In Peru, Fuentes and Wiig (2009) did not find evidence of discrimination of women during a land titling programme. Instead, they found that more women were issued land titles both as individuals and through joint titling with their spouses. Deere and Leon (2003) found that the land distribution of titled lands in Peru was not that unequal if one took account of the jointly held lands. They found that women owned 12.7 percent of the land, men owned 74.4 percent and couples owned 12.8 percent of the land. However, given Goromonzi District's close proximity to Harare and Marondera, the urban influence on the distribution of land between men 
and women cannot be wholly ignored. According to the case study, 43 percent of the land beneficiaries originally came from Harare and Epworth (a dormitory settlement which is 30 kilometres to the east of Harare). The higher number of female land beneficiaries in Bains Hope was attributed to the gender composition of the team of war veterans (one male and three females) who spearheaded the occupation of the farm in 2000.

Inheritance was another avenue through which women accessed land in Goromonzi District. In resettlement areas in Mount Darwin (Mashonaland Central Province) and Mutoko (Mashonaland East Province), Jacobs (2000) found that women could actually inherit the farm holding ahead of the husband's brothers. Goebel (1999) cited in Jacobs (2000) argued that the percentage of widows (30 percent in one village) was high because of the intervention of the Resettlement Officer who had stipulated that the widow should inherit the land. Even more startling to Goebel was that in some cases Resettlement Officers awarded land to married women. In Bains Hope, all the widows had assumed ownership of the plots while some were still in the process of transferring ownership of the plots into their names. The inheritance procedure involved obtaining a letter confirming death of spouse from the headman or headwoman (in addition to the death certificate of the farm holder) and submitting a letter of application of change of ownership to the District Administrator through the District Lands Officer. Given that the offer letter has provisions for a maximum of two spouses and three children, the inheritance procedure is more explicit in resettlement areas than in the communal areas though it discriminates against other dependent children and additional spouses. On the other hand, in the communal areas, legislation is silent on the issue of married women's rights to inherit the land in the event of the death of the husband intestate. Many women who remained on the land in the communal areas did so at the goodwill of their in-laws or traditional leaders. In Uganda, Tripp (2012) citing West (1972) and Trout (1994) found that although it was not traditionally customary for women to inherit land, an increasing number of women did although they inherited smaller portions of land than men.

Jacobs (2000) observed that an unmarried woman had no claim on land. This is contrary from what was observed in Goromonzi District where both married and unmarried women had equal access to land. Jacobs (2000) and Ncube et al., (1997) noted that a wife's access to land depended upon the marriage continuing since upon divorce it was she who had to leave the resettlement area. Where women lost their right to land in A1 schemes, it was "consensual" with their spouses. The District Lands Officer recalled there were cases where some women, after being allocated land refused to have their names on the offer letters as beneficiaries and instead requested that their names should be replaced with those of their husbands as farm holders.

A pertinent question to ask is how such a highly politicised land redistribution programme did not discriminate against women? Women were not passive spectators of the farm occupations and had strong social assets of being active members of ZANU-PF which guaranteed their allocation of land. A significant number of women beneficiaries in the two study sites confirmed that they were able to obtain land because of their party, ZANU-PF.

\section{Answering research question two}

The second research question was aimed at establishing if women had the same land rights as men in A1 resettlement areas. The results from the t-test and chi-squared test of independence as well as evidence from Goromonzi District showed that women beneficiaries of the FTLRP obtained the same land rights as men in terms of land use patterns. The land use patterns focused on the mean sizes of arable land allocated to men and women and the predominant type and/or quality of soil on the A1 farm holdings.

However, there is no denying that more men than women benefitted under the FTLRP. The survey data showed that 78.5 percent of the land beneficiaries were male while 21.5 percent were female. This was because the government used the household as the beneficiary unit. Although this approach provided female members of the household with access to land, it may have undermined their bargaining power (FAO, 2007). Zimbabwe is a predominantly patriarchy society where most households are headed by males. Various studies have shown that more men than women were allocated land under the A1 model (Chingarande, 2008; Gaidzanwa, 2011; GOZ, 2003; ZWRCN, 2008). The Utete Report (2003) shows that less than 20 percent female-headed households were allocated land under the FTLP for the different provinces. The use of a household as the beneficiary unit was based on the unitary agricultural household model. According to the unitary agricultural household model, an altruistic head ensures equitable allocations of goods and tasks (Becker, 1981 cited in Agarwal, 2003) in order to maximise household utility. Some authors (Haddad and Kanbur, 1990, Duflo and Udry, 2004 and Sen, 1990 cited in Doss et al., 2008; Haddad et al., 1997) have shown that household welfare is not equivalent to the welfare of the individuals within it. This led to the rejection of the unitary household model (Agarwal, 1997, 2003; Cohen, 1996; Haddad et al., 1997; Strauss and Thomas, 1995 and Behrman, 1997 cited in Meinzen-Dick et al., 2011; Quisumbing, 2003; Stowhase, 2009). The intra-household models on the other hand, are based on bargaining, conflict and unequal power relations between married partners (Haddad et al., 1997) and thus help to analyse the distributional effects of household resources to the individual members. 
Hypothesis two (H2) and hypothesis three (H3) were used to answer research question two. H2 sought to measure gender asset gap in terms of the mean sizes of arable land cultivated by men and women in A1 resettlement areas using the independent t-test. There was no evidence of gender asset gap in A1 schemes when using the mean sizes of arable land being cultivated by men and women. The survey data collected by AIAS (2006) showed that women's landholdings were in fact marginally greater than men's: the average size of women's plots is 8.39 hectares compared to 8.10 hectares for men. This result was supported by the researcher's own anecdotal evidence in Goromonzi District where women's and men's arable plots were of equal size. The sizes of arable plots were determined by the Government and varied between provinces depending on the agroecological region. In the communal areas, the average size of women's landholdings is 1.86 hectares compared with 2.73 hectares for men (Doss et al., 2008). In Egypt, the average farm size for men is 1.7 hectares while the average farm size for women is 0.7 hectares (ibid). These findings showed that women in A1 schemes did not only have access to bigger arable plots than their counterparts in the communal areas but even those in Africa. Based on the independent t-test and findings from the case study, the fourth hypothesis was rejected since the mean sizes of arable land for men and women were statistically equal.

H3 tested gender differentials with respect to soil type and/or quality. The results of the chi-squared test of independence between predominant type of soil and sex of the farm holder did not allow the researcher to keep the hypothesis that women tended to have land rights on farm holdings with worse soil types than men. This was also supported by evidence from Goromonzi District. For those successful applicants, plots were allocated through a random process which made it "impossible" to discriminate between men and women based on the predominant soil type on the farm holding. According to Feder et al., (1998), soil types defer among farmers which further diminished chances of discrimination.

The distribution of land rights between men and women mirrored the distribution of assets, division of labour and decision making within households. Empirical evidence from the case study showed that a spouse's bargaining power could be enhanced through access to and control over land. This was demonstrated by joint decisions in the acquisition and disposal of both household and productive assets and consultative processes on key agricultural activities and utilisation of the income derived from the agricultural enterprise. Testimonies by women in the two study sites depicted an improvement in their socio-economic status and food security as well as improved sense of dignity. In the study area, 54.1 percent of the respondents indicated that both husband and wife made joint decisions to acquire and/or dispose of productive assets. This was because both spouses contributed to the agricultural enterprise in different ways. About 37.8 percent of the respondents indicated that women were directly involved in the marketing of agricultural products and had considerable influence on the use of the income. This demonstrated that income from agriculture had value in changing gender roles and relations in the household and probably the whole community. This was supported by previous studies. Empirical evidence from Bangladesh, Peru and the Philippines demonstrates how increases in women's income earnings result in greater investments in education and health (Doss et al., 2008). In 2003 married working women in Bangladesh claimed that they had greater decision-making power in the household because of their wage income (Raworth, 2004 cited in Doss et al., 2008). The FTLRP offered married women space to engage in non-agricultural livelihoods-enhancing strategies (such as nutrition gardens, business enterprise and vending) that provided them with independent sources of income. These increased opportunities for women improved household welfare (through increased income), gender equality and empowerment.

Married women in the study sites confirmed that they gained considerable respect within their own households and community at large after they were allocated land under the FTLRP. Fieldwork in Goromonzi District showed that women empowerment through land access gave them a strengthened status and ability to challenge structures of patriarchy within the household. In India, Agarwal (1994) found that land ownership provided widows with greater respect and consideration while Allendorf (2007) observed that women who owned land had final say in household decisions in Nepal. The finding confirmed an earlier observation that an individual's bargaining power was determined by his or her control over economic resources (Quisumbig and Maluccio, 2000; Agarwal, 2003).

During interviews with A1 farmers some revealed that they had virtually no assets when they were allocated land in 2000/2001 and that their livelihoods were now comparatively better in A1 schemes than communal areas. From the questionnaire, 94.6 percent answered that their asset holding increased after acquiring A1 farm holdings. The assets mostly mentioned included bigger houses (with either asbestos or zinc roof types), more livestock (mostly cattle) and productive assets (tractors, lorries, ox ploughs, scotch carts and ox cultivators) which they bought after selling crops. Most farmers attributed their improved welfare to richer soils and greater opportunities for a range of alternative livelihoods strategies besides agriculture. For the farmers who answered "no" attributed their predicament to either theft or fire. They did not mention poor soils or unavailability of agricultural inputs as the cause for their not accumulating assets. This showed that A1 farmers regarded farming as a productive business enterprise. 
The researcher observed that farm labour was shared between the family and hired labour. The gendered relations of production still shaped the division of labour between males and females within the same farming household. This also extended to hired labour which comprised both males and females although female labour predominated. There was more female labour because some of the male farm workers were involved in informal activities such as vending in Harare. Land preparation was mostly done by hired labour (23 percent) while planting and hoeing (or weeding) were mainly done by family members (27 and 26 percent respectively). The harvesting of crops was done by family labour (31 percent). In terms of time budgets, women spent more time on agricultural activities than men. This confirmed an earlier observation by Saito et al., (1994) that women worked for longer hours in Burkina Faso, Kenya, Nigeria and Zambia.

From document analysis and fieldwork in Goromonzi district, the allocation of arable plots was random and hence there was no discrimination between male and female beneficiaries. In the study sites, 84 percent of the women interviewed indicated that the distribution of land rights between men and women was equal in Goromonzi District. The women respondents explained that men and women were allocated plots in the same area without regard to marital status or sex.

\section{Conclusion}

The study showed that men and women received the same land rights in A1 schemes in terms of mean farm size and predominant soil type on the farm holding. This confirmed that there was no evidence of gender asset gap in A1 schemes when using the mean farm size for men and women. The study actually showed that women's landholdings were in fact marginally greater than men's: the average size of women's plots is 8.39 hectares compared to 8.10 hectares for men.

The study recommended that allocation of land under the land reform programme should focus on individuals within households in order to close gender asset gap. Government officials directly involved in the design, planning and implementation of the land reform programme should be trained in gender analysis and participatory gender planning. Methods should be devised to inform women about their land rights and the avenues through which these rights can be enforced and women need to be represented in district and village land committees.

The study had also sought to assess land use patterns in terms of availability of agricultural infrastructure particularly irrigation between men and women. By completing this study, the researcher has not addressed this objective due to the unavailability of data. Further research may be undertaken towards finding out if women have less access to irrigation infrastructure than men.

\section{References}

[1]. AIAS, (2006). The Fast Track Land Reform Programme Household Baseline Survey. Harare: AIAS.

[2]. Agarwal, B. 1997). "Bargaining" and Gender Relations: Within and Beyond the Household. Feminist Economics, Vol. 3 No.1, pp1-51(2003). Gender and Land Rights Revisited: Exploring New Prospects via the State, Family and Market, Journal of Agrarian Change, Vol.3 Nos. 1 and 2, pp184-224

[3]. Allendorf, K. (2007). Do women's land rights promote empowerment and child health in Nepal? World Development, 35 (11): 1975-1988

[4]. Bryman, A. E. (2001). Social Research Methods. Oxford: Oxford University Press

[5]. Chaumba, J., Scoones, I., and Wolmer, W., (2003). From Jambanja to Planning: The reassertion of technocracy in land reform in Southeastern Zimbabwe. Journal of Modern African Societies. Vol.41 No.4, pp533-554

[6]. Chingarande S. (2008). Gender and the Struggle for Equity, in Moyo S. et al. 2008, Contested Terrain: Land Reform and Civil Society in Contemporary Zimbabwe. Pietermaritzburg, S \& S Publishers.

[7]. Cohen, M. (1996). Household Economic Portfolios, More infowww.eldis.org/vfile/upload/1/document/0708/DOC2932.pdf, (18 November 2010)

[8]. Deere, C.D. and Doss, C.R. (2006). Gender and the Distribution of Wealth in Developing Countries, Helsinki: UNU-WIDER. http://www.wider.unu.edu/stc/repec/pdfs/rp2006/rp2006-115.pdf, (Accessed on 26 May 2012)

[9]. Deere, C.D. and León, M. (2003). The Gender Asset Gap: Land in Latin America. World Development, Vol.31 No.6, pp925-947 http://www.sciencedirect.com/science/article/B6VC6-48GNT6H-1/2/a67c68c7e9bc792698e67b3eabe45877 (Accessed on 26 May 2012)

[10]. Deininger, K., Hoogeveen, H., and Kinsey, B.H., (2002). "Benefits and Costs of Land Reform in Zimbabwe with Implications for Southern Africa. Paper presented at the Centre for Study of African Economies Conference, "Understanding Poverty and Growth in Sub-Saharan Africa" St. Catherine's College, Oxford, U.K., March 18-19, 2002.

[11]. $\quad$ http://www.csae.ox.ac.uk/conferences/2002-UPaGiSSA/papers/Hoogeveen-csae2002.pdf, (Accessed on 5 October 2010)

[12]. Doss, C.R., Grown C., and Deere, C.D., (2008). Gender and Asset Ownership: A Guide to Collecting Individual-Level Data, Policy Research Working Paper, WPS4704, Washington D.C.: World http://elibrary.worldbank.org/docserver/download/4704.pdf?expires=1338036651\&id=id\&accname=guest\&checksum=A6EDB3 FA70120F98A8176EDE417B9101, (Accessed on 26 May 2012)

[13]. Fuentes, D.O and Wiig, H. (2009). Closing the Gender Land Gap-the effects of Land-for Women in Peru.NORLAnet Conference Paper, Socio-Economic Rights/Development, Norwegian Institute of Urban and Regional Research, Oslo, 12-13 November 2009.

[14]. http://www.norlanet.uio.no/pdf/news/announcements/conference_2009_presentations/fue ntes_and_wiig.pdf. (Accessed on 18 February 2011)

[15]. Gaidzanwa, R. B. (2011). Women and Land in Zimbabwe, Paper presented at the Conference "Why women matter in agriculture" Sweden, April 4-8, 
http://siani.clients.codepositive.com/sites/clients.codepositive.com/files/document/rudo_ women_and_land_in_zimbabwe.pdf (Accessed on 19 September 2012)

[16]. GOZ, (1998b). Land Reform and Resettlement Programme Phase II: Policy Framework and Project Document, Harare.

[17]. (2003). Report of the Presidential Land Review Committee on the Implementation of the Fast Track Land Reform Programme "The Utete Report", Harare. http://www.sarpn.org.za/documents/d0000622/P600-Utete_PLRC_00-02.pdf, (Accessed on 12 February 2011)

[18]. Gujarati, D. N. (1988). Basic Econometrics: (2 ${ }^{\text {nd }}$ ed.). New York: McGraw-Hill Book Co.

[19]. Gujarati, D. N. (1999). Essentials of Econometrics: (2 ${ }^{\text {nd }}$ ed.). Singapore: McGraw-Hill Book Co.

[20]. Haddad, L., Hoddinott, J. and Alderman, H. (eds) (1997). Intrahousehold Resource Allocation in Developing Countries: Models, Methods and Policy, Baltimore MD: Johns Hopkins University Press.

[21]. Jacobs, S. (2000). Zimbabwe: Why Land Reform is a Gender Issue. Sociological Research Online, Vol.5 No. 2, pp301-314 http://www.socresonline.org.uk/5/2/jacobs.html (Accessed on 7 May, 2012)

[22]. Landau, S. and Everitt, B.S. (2004). A Handbook of Statistical Analyses using SPSS. New York: Chapman \& Hall/CRC Press Co.

[23]. http://gs.utcc.ac.th/ceomba/mk/0\%2055/BI528/Handbook\%20of\%20SPSS\%20\%20Step\%20by\%20Step/eBook\%20x\%20SPSS Statistical Analyses using SPSS.pdf(Accessed on 4 February 2013)

[24]. Marongwe, N.(2002). Conflicts over Land and other Natural Resources in Zimbabwe. Harare: ZERO Regional Environment Organisation.(2008). Interrogating Zimbabwe's Fast Track Land Reform and Resettlement Programme: a focus on beneficiary selection. Unpublished DPhil Thesis, University of Western Cape.

[25]. Masiiwa, M. and Chipungu, L. (2004). Land Reform Programme in Zimbabwe: Disparity between Policy Design and Implementation in Masiiwa M. (eds) Post-Independence Land Reform in Zimbabwe: Controversies and Impact in the Economy. Harare: Friedrich Ebert Stiftung and Institute of Development Studies, University of Zimbabwe.

[26]. Meinzen-Dick, R. et al. (2011). Gender, Assets and Agricultural Development Programs: A Conceptual Framework. CAPR Working Paper No.99. Washington D.C.: International Food Policy Research Institute. http://www.capri.cgiar.org/pdf/capriwp99.pdf (Accessed on 16 October 2012)

[27]. Ncube ,W. et al. (1997). Paradigms of Exclusion: Women's access to resources in Zimbabwe. Harare: Women and Law in Southern Africa Research Project.

[28]. Quisumbing, A. R. and Maluccio, J.A. (2000). Intra-household Allocation and Gender Relations: New Empirical Evidence from Four Developing Countries, International Food Policy Research Division Discussion Paper No.84 www.ifad.org/gbdocs/gc/26/e/women.pdf, (Accessed on 10 December 2010)

[29]. Sachikonye, L.M. (2003). The Situation of Commercial Farm Workers after Land Reform in Zimbabwe, A report prepared for the Farm Community Trust of Zimbabwe, London: CIIR. http://www.kubatana.net/docs/landr/fctz_farm_workers_0305.pdf (Accessed on $10 \quad$ March 2012)

[30]. Saito, K.A., Mekonnen, H. and Spurling, D. (1994). Raising the Productivity of Women Farmers in Sub-Saharan Africa (World Bank Discussion Paper 230), Washington D.C.: World Bank.

[31]. Saunders, M., Lewis, P., and Thornhill, A., (2009). Research Methods for Business Students. ( $5^{\text {th }}$ ed.). Harlow: Prentice Hall.

[32]. Scoones, I., Marongwe, N., Mavedzenge, B., Murimbarimba, F. and Mahenehene, J. (2010). Zimbabwe's Land Reform: Myths and Realities. Harare: Weaver Press

[33]. Sithole, B., Campbell, B. Doré, D. and Kozanayi, W. (2003). "Narratives on Land: State-Peasant Relations Over Fast Track Land Reform In Zimbabwe." African Studies Quarterly Vol.7no.2\&3:http://web.africa.ufl.edu/asq/v7/v7i2a4.htm. (Accessed on 27 February 2012)

[34]. Tripp, A.M. (2012).Women's Movements, Customary Law and Land Rights in Africa: the Case of Uganda. African Studies Quarterly Vol.13 no.1\&2 http://www.africa.ufl.edu/asq/v7/v7i4a1.pdf (Accessed on 26 April 2013)

[35]. UNDP, (2002). Zimbabwe's Land Reform and Resettlement. UNDP Interim Mission Report, January 2002, Harare: UNDP.

[36]. Verbeek, M. (2008). A Guide to Modern Econometrics. ( $3^{\text {rd }}$.). West Sussex, UK. John Wiley \& Sons Ltd.

[37]. ZWRCN, (1998). Beyond Inequalities: Women in Zimbabwe. Harare: ZWRCN.(2008). Situational Analysis on the Gender Gaps in the Agricultural Sector in Zimbabwe. Harare: ZWRCN.

\section{APPENDIX A}

Table A 1 Chi-square test of the relationship between category of landholding and availability of offer letter in Mashonaland East Province

\begin{tabular}{|c|c|c|c|c|c|}
\hline \multirow[t]{2}{*}{$\begin{array}{l}\text { Do you have an } \\
\text { offer letter? }\end{array}$} & \multicolumn{5}{|c|}{ Under whose name is the farm holding registered? } \\
\hline & Household head & Spouse & Joint registration & Other & Total \\
\hline $\begin{array}{l}\text { Yes } \\
(=1)\end{array}$ & $\begin{array}{l}499 \\
97.7 \\
84.9\end{array}$ & $\begin{array}{l}10 \\
2.0 \\
90.0\end{array}$ & $\begin{array}{l}1 \\
0.2 \\
50\end{array}$ & $\begin{array}{l}1 \\
0.2 \\
100\end{array}$ & $\begin{array}{l}511 \\
100 \\
84.9\end{array}$ \\
\hline $\begin{array}{l}\text { No } \\
(=0)\end{array}$ & $\begin{array}{l}89 \\
97.8 \\
15.1\end{array}$ & $\begin{array}{l}1 \\
1.1 \\
9.1\end{array}$ & $\begin{array}{l}1 \\
1.1 \\
50\end{array}$ & $\begin{array}{l}0 \\
0.0 \\
0.0\end{array}$ & $\begin{array}{l}91 \\
100 \\
15.1\end{array}$ \\
\hline Total & $\begin{array}{l}588 \\
97.7 \\
100 \\
\end{array}$ & $\begin{array}{l}11 \\
1.8 \\
100 \\
\end{array}$ & $\begin{array}{l}1 \\
0.002 \\
100 \\
\end{array}$ & $\begin{array}{l}1 \\
0.002 \\
100 \\
\end{array}$ & $\begin{array}{l}602 \\
100 \\
100 \\
\end{array}$ \\
\hline \multicolumn{6}{|c|}{ Pearson Chi-square $=2.386$} \\
\hline
\end{tabular}


Table A 2 Chi-square test of the relationship between category of landholding and availability of offer letter in Mashonaland West Province

\begin{tabular}{|c|c|c|c|c|}
\hline \multirow[t]{2}{*}{ Do you have an offer letter? } & \multicolumn{4}{|c|}{ Under whose name is the farm holding registered? } \\
\hline & Household head & Spouse & Joint registration & Total \\
\hline $\begin{array}{l}\text { Yes } \\
(=1)\end{array}$ & $\begin{array}{l}157 \\
87.7 \\
84.4\end{array}$ & $\begin{array}{l}21 \\
11.7 \\
87.5\end{array}$ & $\begin{array}{l}1 \\
0.6 \\
100\end{array}$ & $\begin{array}{l}179 \\
100 \\
84.8\end{array}$ \\
\hline $\begin{array}{l}\text { No } \\
(=0)\end{array}$ & $\begin{array}{l}29 \\
90.6 \\
15.6\end{array}$ & $\begin{array}{l}3 \\
9.4 \\
12.5\end{array}$ & $\begin{array}{l}0 \\
0.0 \\
0.00\end{array}$ & $\begin{array}{l}32 \\
100 \\
15.2\end{array}$ \\
\hline Total & $\begin{array}{l}186 \\
88.2 \\
100\end{array}$ & $\begin{array}{l}24 \\
11.4 \\
100\end{array}$ & $\begin{array}{l}1 \\
0.004 \\
100\end{array}$ & $\begin{array}{l}211 \\
100 \\
100\end{array}$ \\
\hline \multicolumn{5}{|c|}{ Pearson Chi-square $=0.338$} \\
\hline
\end{tabular}

Table A 3 Chi-square test of the relationship between category of landholding and availability of offer letter in Masvingo Province

\begin{tabular}{|c|c|c|c|c|c|}
\hline \multirow[t]{2}{*}{$\begin{array}{l}\text { Do you have an } \\
\text { offer letter? }\end{array}$} & \multicolumn{5}{|c|}{ Under whose name is the farm holding registered? } \\
\hline & Household head & Spouse & Joint registration & Other & Total \\
\hline $\begin{array}{l}\text { Yes } \\
(=1)\end{array}$ & $\begin{array}{l}147 \\
94.8 \\
90.7\end{array}$ & $\begin{array}{l}6 \\
3.9 \\
85.7\end{array}$ & $\begin{array}{l}1 \\
0.6 \\
50\end{array}$ & $\begin{array}{l}1 \\
0.6 \\
100\end{array}$ & $\begin{array}{l}155 \\
100 \\
81.9\end{array}$ \\
\hline $\begin{array}{l}\text { No } \\
(=0)\end{array}$ & $\begin{array}{l}15 \\
88.2 \\
9.3\end{array}$ & $\begin{array}{l}1 \\
5.9 \\
14.4\end{array}$ & $\begin{array}{l}1 \\
5.9 \\
50\end{array}$ & $\begin{array}{l}0 \\
0.0 \\
0.0\end{array}$ & $\begin{array}{l}17 \\
100 \\
18.1\end{array}$ \\
\hline Total & $\begin{array}{l}162 \\
94.2 \\
100 \\
\end{array}$ & $\begin{array}{l}7 \\
4.1 \\
100 \\
\end{array}$ & $\begin{array}{l}2 \\
1.2 \\
100\end{array}$ & $\begin{array}{l}1 \\
0.6 \\
100 \\
\end{array}$ & $\begin{array}{l}172 \\
100 \\
100 \\
\end{array}$ \\
\hline \multicolumn{6}{|c|}{ Pearson Chi-square $=3.947$} \\
\hline
\end{tabular}

Table A 4 Chi-square test of the relationship between category of landholding and availability of offer letter in Midlands Province

\begin{tabular}{|c|c|c|c|c|c|}
\hline \multirow[t]{2}{*}{$\begin{array}{l}\text { Do you have an } \\
\text { offer letter? }\end{array}$} & \multicolumn{5}{|c|}{ Under whose name is the farm holding registered? } \\
\hline & Household head & Spouse & Joint registration & Other & Total \\
\hline $\begin{array}{l}\text { Yes } \\
(=1)\end{array}$ & $\begin{array}{l}241 \\
97.6 \\
68.5\end{array}$ & $\begin{array}{l}3 \\
1.2 \\
100\end{array}$ & $\begin{array}{l}2 \\
0.8 \\
66.7\end{array}$ & $\begin{array}{l}1 \\
0.4 \\
100\end{array}$ & $\begin{array}{l}247 \\
100 \\
68.8\end{array}$ \\
\hline $\begin{array}{l}\text { No } \\
(=0)\end{array}$ & $\begin{array}{l}111 \\
99.1 \\
31.5\end{array}$ & $\begin{array}{l}0 \\
0.0 \\
0.0\end{array}$ & $\begin{array}{l}1 \\
0.9 \\
33.3\end{array}$ & $\begin{array}{l}0 \\
0.0 \\
0.0\end{array}$ & $\begin{array}{l}112 \\
100 \\
31.2\end{array}$ \\
\hline Total & $\begin{array}{l}352 \\
98.1 \\
100 \\
\end{array}$ & $\begin{array}{l}3 \\
0.8 \\
100 \\
\end{array}$ & $\begin{array}{l}3 \\
0.3 \\
100 \\
\end{array}$ & $\begin{array}{l}1 \\
0.8 \\
100 \\
\end{array}$ & $\begin{array}{l}359 \\
100 \\
100 \\
\end{array}$ \\
\hline \multicolumn{6}{|c|}{ Pearson Chi-square $=1.839$} \\
\hline
\end{tabular}


Table A 5 Chi-square test of the relationship between category of landholding and availability of offer letter in Matabeleland South Province

\begin{tabular}{|l|l|l|l|}
\hline \multirow{2}{*}{ Do you have an offer letter? } & \multicolumn{3}{|c|}{ Under whose name is the farm holding registered? } \\
\cline { 2 - 4 } & Household head & Spouse & Total \\
\hline $\begin{array}{l}\text { Yes } \\
(=1)\end{array}$ & 27 & 76 & $\mathbf{1 0 3}$ \\
& 26.2 & 73.8 & $\mathbf{1 0 0}$ \\
\hline $\begin{array}{l}\text { No } \\
(=0)\end{array}$ & 93.1 & 96.2 & $\mathbf{9 5 . 4}$ \\
& 2 & 3 & $\mathbf{5}$ \\
\hline Total & 40 & 60 & $\mathbf{1 0 0}$ \\
& 6.9 & 3.8 & $\mathbf{4 . 6}$ \\
& $\mathbf{2 9}$ & $\mathbf{7 9}$ & $\mathbf{1 0 8}$ \\
& $\mathbf{2 6 . 9}$ & $\mathbf{7 3 . 1}$ & $\mathbf{1 0 0}$ \\
\hline & $\mathbf{1 0 0}$ & $\mathbf{1 0 0}$ & \\
\hline
\end{tabular}

